\title{
The Physiological Role of Thyrotropin-Releasing Hormone in the Regulation of Thyroid-Stimulating Hormone and Prolactin Secretion in the Rat
}

\author{
arthur R. C. Harris, Dana Christianson, M. Susan Smith, Shih-lieh Fang, \\ Lewis E. Braverman, and Apostolos G. Vagenakis, Departments of \\ Endocrinology and Physiology, University of Massachusetts Medical School, \\ Worcester, Massachusetts 01605
}

A B S TRACT The physiological role of thyrotropinreleasing hormone (TRH) in the regulation of thyrotropin (thyroid-stimulating hormone, TSH) and prolactin (Prl) secretion has been assumed but not proven. Stimulation of their release requires pharmacologic doses of TRH. Lesions of the hypothalamus usually induce an inhibition of TSH secretion and an increase in Prl. To determine whether TRH is essential for TSH and $\mathrm{Prl}$ secretion in the rat, $0.1 \mathrm{ml}$ of TRH antiserum (TRH-Ab) or normal rabbit serum was administered to normal, thyroidectomized, cold-exposed, and proestrus rats through indwelling atrial catheter. Serum samples were obtained before and at frequent intervals thereafter. Serum TSH concentrations in normal, thyroidectomized, cold-exposed, and proestrus rats were not depressed in specimens obtained up to $24 \mathrm{~h}$ after injection of normal rabbit serum. In contrast, serum TSH was significantly decreased after the administration of TRH-Ab in all normal (basal, $41 \pm 8$ $\mu \mathrm{U} / \mathrm{ml}[$ mean $\pm \mathrm{SE}$ ]; $30 \mathrm{~min}, 6 \pm 2 ; 45 \mathrm{~min}, 8 \pm 3 ; 75 \mathrm{~min}$, $4 \pm 2$ ); thyroidectomized (basal, $642 \pm 32 \mu \mathrm{U} / \mathrm{ml} ; 30 \mathrm{~min}$, $418 \pm 32$; $60 \mathrm{~min}, 426 \pm 36$; $120 \mathrm{~min}, 516 \pm 146$ ); coldstressed (basal, $68 \pm 19 \mu \mathrm{U} / \mathrm{ml} ; 30 \mathrm{~min}, 4 \pm 3 ; 180 \mathrm{~min}$, $16 \pm 8$ ); and proestrus (basal, 11 a.m., $57 \pm 10 \mu \mathrm{U} / \mathrm{ml} ; 1$ p.m., $20 \pm 3 ; 3$ p.m., $13 \pm 4 ; 5$ p.m., $19 \pm 3$ ) rats. However, $0.1 \mathrm{ml}$ of TRH-Ab had no effect on basal Prl concentrations in normal or thyroidectomized rats and did not prevent the $\mathrm{Prl}$ rise in rats exposed to cold (basal, $68 \pm 7 \mathrm{ng} / \mathrm{ml}$; $15 \mathrm{~min}, 387 \pm 121$; $30 \mathrm{~min}, 212 \pm 132$; $60 \mathrm{~min}, 154 \pm 114$ ), or the Prl surge observed on the afternoon of proestrus (basal 11 a.m., $23 \pm 2 \mathrm{ng} / \mathrm{ml} ; 1$

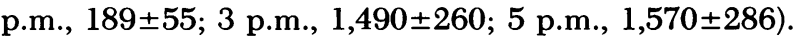

This work was presented in part at the 69th Annual Meeting of the American Society for Clinical Investigation, Washington D. C., May 1977.

Received for publication 5 July 1977 and in revised form 27 September 1977.
These studies demonstrate that TRH is required for TSH secretion in the normal, cold-exposed and proestrus rat and contributes, at least in part, to TSH secretion in the hypothyroid rat, but is not required for Prl secretion in these states.

\section{INTRODUCTION}

The administration of pharmacologic doses of thyrotropin-releasing hormone (TRH) ${ }^{1}$ has been demonstrated to stimulate thyrotropin (thyroid-stimulating hormone, TSH) and prolactin (Prl) synthesis and release from the anterior pituitary (1-5). Surgical or pathologic lesions of the hypothalamus have resulted in decreased TSH release and subsequent hypothyroidism $(6-10)$. It is well established that Prl secretion is tonically suppressed by dopamine either by a direct effect on the pituitary or by modulating the release of the Prl inhibiting factor. Median eminence and pituitary stalk lesions usually enhance rather than suppress Prl secretion (11, 12), although this is not always observed in unstressed rats after hypothalamic deafferentation (13). In intact animals, electrical stimulation of the hypothalamic "hypophysiotropic area" (14) has been shown to increase serum TSH levels $(10,15)$, presumably secondary to TRH release, although direct experimental evidence of enhanced TRH release is lacking. The effect of such electrical stimulation on Prl secretion is variable (16). The alterations in TSH or Prl release after hypothalamic lesions or electrical stimulation may be nonspecific and the observed changes secondary to the inhibition or

\footnotetext{
'Abbreviations used in this paper: Prl, prolactin; NRS, normal rabbit serum; $\mathrm{T}_{3}$, Triiodothyronine; $\mathrm{T}_{4}$, thyroxine; TCA, trichloroacetic acid; TRH, thyrotropin-releasing hormone; TRH-Ab, TRH-antiserum; TSH, thyroid-stimulating hormone; RIA, radioimmunoassay.
} 
release of factors other than TRH. Increased serum TSH and Prl concentrations have been observed in suckling rats $(17,18)$, but breast-feeding in man is associated with normal serum TSH and increased $\mathrm{Prl}$ concentrations (19). A concomitant increase in the serum concentrations of TSH and Prl has been reported in some patients with primary hypothyroidism (20-24) and in rats exposed to the cold $(25,26)$.

To clarify the physiological role of TRH on TSH and Prl secretion, a nontoxic substance that selectively inactivates TRH in vivo could be employed. Recently, specific antisera have been administered in vivo to bind somatostatin (27-29), luteinizing hormone releasing hormone (30-32), and TRH (33). This study reports the effect of a specific TRH antibody administered to normal, thyroidectomized, proestrus, and cold-exposed rats on the serum concentrations of TSH and $\mathrm{Prl}$ measured by radioimmunoassay (RIA), and on the biological activity of TSH as assessed by thyroid function.

\section{METHODS}

Male or female Sprague-Dawley rats, 50- to 70-days old and weighing between 180 and $250 \mathrm{~g}$, were obtained from the Charles River Breeding Laboratories, Wilmington, Mass. They were housed individually in wire mesh cages and fed Charles River chow or low iodine diet and tap water ad libitum. Rooms were lighted from 7 a.m. to 8 p.m. and room temperature was maintained at $21 \pm 1^{\circ} \mathrm{C}$. All animals were handled once or twice daily for 4 days preceeding each experiment to avoid external stress on the day of the experiment.

TRH antibody. The antisera to TRH was raised in rabbits after subcutaneous injections of synthetic TRH (Abbott Laboratories, Diagnostics Div., South Pasadena, Calif.) coupled to bovine serum albumin (BSA) by the bisdiazotized benzidine method, as described by Bassiri and Utiger (34). One TRH antiserum (TRH-Ab) so obtained has been successfully used in a TRH radioimmunoassay as described (35). The binding capacity was $4.6 \mu \mathrm{mol} / \mathrm{liter}$ and the affinity constant $(K) 8.1 \times 10^{8} \mathrm{liter} / \mathrm{mol} .2 \mathrm{pg}$ TRH was detected by this antibody in the TRH radioimmunoassay. Because $0.2 \mathrm{ml}$ or more of normal rabbit serum (NRS) administered i.v. resulted in an artifactual decrease in the measurements of TSH and $\mathrm{Prl}$ in assays employing rabbit antisera and goat anti-rabbit gamma globulin as the second antibody, smaller quantities $(0.1 \mathrm{ml})$ of TRH-Ab and NRS were administered to the rat in all experiments in which TSH and Prl assays were carried out. This quantity of NRS administered in vivo did not interfere with the RIA of TSH, Prl, or triiodothyronine $\left(\mathrm{T}_{3}\right)$.

Normal rats. $24 \mathrm{~h}$ before each experiment, right atrial cannula with Silastic tips (602-135 Silastic medical grade tubing, Dow Corning Corp., Midland, Mich.) were inserted under ether anesthesia and exteriorized to the back of the neck. Heparin was not used. At 8 a.m. on the morning of the experiment, $0.4 \mathrm{ml}$ of blood was withdrawn, followed immediately by the administration of TRH-Ab or NRS through the catheter. Additional 0.4-ml blood samples were obtained 30,40 , and $75 \mathrm{~min}$ and $24 \mathrm{~h}$ later in one experiment and at 30 and $120 \mathrm{~min}$ in another. Volume was replaced with normal saline. Blood was quickly spun, serum separated, and stored at $-20^{\circ} \mathrm{C}$ until assayed for $\mathrm{Prl}, \mathrm{TSH}, \mathrm{T}_{3}$, and thyroxine $\left(\mathrm{T}_{4}\right)$.
Iodine-deficient rats. The biological effect of a decrease in serum TSH was assessed in the rat model as described by Greer et al. (36), who observed that acute hypophysectomy in the iodine-deficient rat resulted in a paradoxical increase in thyroid ${ }^{131}$ I uptake due to an acute inhibition of ${ }^{131}$ I release secondary to a lack of TSH. The effect of acute changes in TSH was determined by measuring the release of ${ }^{131}$ I from the prelabeled thyroid gland. Male rats were fed a low iodine diet containing $34 \mu \mathrm{g} \mathrm{I} / \mathrm{kg}$ for $3 \mathrm{wk}$ and atrial catheters inserted $24 \mathrm{~h}$ before the experiment. At 8 a.m., $1.0 \mathrm{ml}$ blood was obtained through the catheter and either $0.5 \mathrm{ml}$ TRH-Ab or NRS were administered i.v. through the catheter. $30 \mathrm{~min}$ later, $10 \mu \mathrm{Ci}^{131} \mathrm{I}$ was given i.v. Rats were bled and sacrificed 2.5 or $5.5 \mathrm{~h}$ after ${ }^{131}$. Thyroids were quickly removed, weighed, and homogenized in $0.5 \mathrm{ml}$ veronal buffer. Aliquots ( $50 \mu \mathrm{l}$ of a $1: 20$ dilution) of the thyroid homogenates and an appropriately diluted standard were counted in a gamma scintillation counter and the percent ${ }^{131}$ I retained in the thyroid determined. $0.3-\mathrm{ml}$ aliquots of serum were diluted to $0.8 \mathrm{ml}$ by addition of $0.5 \mathrm{ml}$ normal human serum. Protein was precipitated with $0.3 \mathrm{ml}$ of $20 \%$ trichloroacetic acid (TCA) and the precipitate washed twice with $2 \mathrm{ml}$ of $5 \%$ TCA. The TCA precipitate was dissolved in $0.1 \mathrm{ml}$ of $1 \mathrm{~N} \mathrm{NaOH}$, diluted to 3 $\mathrm{ml}$ with saline and counted to determine the serum TCA precipitable and presumably hormonal ${ }^{131} \mathrm{I}$. $\mathrm{T}_{3}$ concentration was measured in ethanol extracts of control sera and sera obtained at 3 and $6 \mathrm{~h}$ after TRH-Ab or NRS administration.

Hypothyroid rats. 5 days after thyroidectomy, rats were cannulated as described above. At 8 a.m. on the second day after cannulation, control serum was obtained and TRH-Ab or NRS then administered through the catheter. Blood specimens were obtained 30,60 , and $120 \mathrm{~min}$ and $24 \mathrm{~h}$ later.

In another series of experiments, atrial catheters were inserted 8 days after thyroidectomy and 1 day later blood was obtained through the catheter. TRH antibodies raised in four different rabbits or NRS were injected i.v. and blood obtained 30 min later. The titer of each TRH-Ab was determined by the final dilution required to bind $30-35 \%{ }^{125}$ I-TRH in the in-vitro RIA for TRH.

Cold-exposed rats. Animals were prepared as described above. $15 \mathrm{~min}$ after the first blood sample was obtained, rats were injected with TRH-Ab or NRS. Single animals were then moved in their individual wire mesh cages to an adjacent cold room and exposed to $4 \pm 1^{\circ} \mathrm{C}$ for $60 \mathrm{~min}$. Blood was obtained 10 , 25 , and $60 \mathrm{~min}$ and $24 \mathrm{~h}$ later. In another experiment, rats were housed in a temperature-controlled environmental room at $25^{\circ} \mathrm{C}$ for 2 days. Temperature was then decreased to $15^{\circ} \mathrm{C}$ by 1 $\mathrm{h}$ and to $4^{\circ} \mathrm{C}$ over the next $2 \mathrm{~h}$. Approximately $15 \mathrm{~min}$ before lowering the temperature, blood was withdrawn through the catheter and TRH-Ab given i.v. Blood was obtained at $1 \mathrm{~h}$ $\left(15^{\circ} \mathrm{C}\right)$ and $3 \mathrm{~h}\left(4^{\circ} \mathrm{C}\right)$ later.

Proestrus rats. Cycling female rats were studied at proestrus after two consecutive 4-day cycles determined by vaginal smear cytology. Aortic cannulation was performed between 7 p.m. and 10 p.m. on the evening of diestrus 2 and catheters flushed with heparinized saline $(16 \mathrm{U} / \mathrm{dl}$ normal saline).

On the day of proestrus, blood was obtained at 11 a.m. The rats were then injected with TRH-Ab or NRS at 12:30 a.m. Blood samples were obtained at 1 p.m., 3 p.m., and 5 p.m. After separation, the plasma was stored at $-20^{\circ} \mathrm{C}$ until assayed for Prl, leuteinizing hormone, and TSH. On the day of estrus, the animals were sacrificed and autopsied to ascertain whether ovulation had occurred. Only rats that had ovulated were included in the final results.

Hormone measurements. Double antibody radioimmunoassays of Prl, TSH, and leuteinizing hormone were carried out with National Institute of Arthritis and Metabolic 
Diseases (National Institutes of Health) kits, using anti-rabbit goat $\gamma$-globulin as a second antibody. Serum $\mathrm{T}_{4}$ concentration was measured by the Corning Solid Phase RIA kit (Corning Medical, Corning Glass Works, Medfield, MA). Serum $\mathrm{T}_{3}$ concentration was measured by RIA as described (37). All specimens from individual experiments were measured in duplicate in the same assay. Statistical analysis was carried out by unpaired Student's $t$ or paired $t$ test (38).

\section{RESULTS}

Effect of TRH-Ab on serum TSH and Prl concentrations, and thyroid function in the normal rat. The administration of TRH-Ab strikingly decreased the mean serum TSH concentration from a control value of $135 \pm 25 \mu \mathrm{U} / \mathrm{ml}($ mean $\pm \mathrm{SE})$ to $57 \pm 9$ at $30 \mathrm{~min}$ and to $45 \pm 8$ at $2 \mathrm{~h}$ (Table I). In contrast, NRS did not affect the serum TSH concentration. The mean serum $\mathrm{Prl}$ concentration was unaffected by either TRH-Ab or NRS. In another experiment, TRH-Ab again decreased serum TSH from a control value of $41.4 \pm 8 \mu \mathrm{U} / \mathrm{ml}$ to almost undetectable levels at $30 \mathrm{~min}$. The mean serum TSH concentration remained essentially undetectable for at least $75 \mathrm{~min}$ and returned to control values at $24 \mathrm{~h}$ $(35 \pm 5 \mu \mathrm{U} / \mathrm{ml})$. In contrast, NRS did not affect the mean serum TSH concentration. The decrease in serum TSH concentration resulted in a progressively significant decrease in serum $T_{3}$ concentration in rats treated with TRH-Ab, whereas NRS had no effect (Fig. 1). Serum $\mathrm{T}_{4}$ concentration remained unchanged in both groups.

In iodine-deficient rats (Fig. 2), the $2.5 \mathrm{~h}$ thyroid ${ }^{131} \mathrm{I}$ uptake was slightly increased in animals receiving TRH-Ab as compared to those given NRS $(39.6 \pm 1.6 \mathrm{vs}$. $35.2 \pm 2.8 \%$; NS) and at $5.5 \mathrm{~h}$, this increase was significant $(42.5 \pm 3.0$ vs. $34.0 \pm 1.5 \% ; P<0.05)$. The serum TCA precipitable ${ }^{131} \mathrm{I}$ was decreased in TRH-Ab rats at $2.5 \mathrm{~h}(526 \pm 38$ vs. $1,045 \pm 187 \mathrm{cpm} / \mathrm{ml} ; P<0.05)$ and strikingly decreased at $5.5 \mathrm{~h}(510 \pm 45 \mathrm{vs} .3,896 \pm 811$ $\mathrm{cpm} / \mathrm{ml} ; \quad P<0.005) . \mathrm{T}_{3}$ concentrations in ethanol extracts of serum were significantly decreased $3 \mathrm{~h}$ $(115 \pm 11 \mathrm{vs} .81 \pm 7 \mathrm{ng} / \mathrm{dl}$; paired $t$ test, $P<0.005)$ and $6 \mathrm{~h}$ $(112 \pm 7$ vs. $58 \pm 5 \mathrm{ng} / \mathrm{dl}$; paired $t$ test, $P<0.001)$ after $\mathrm{TRH}-\mathrm{Ab}$ administration. In contrast, the mean serum $\mathrm{T}_{3}$

\section{TABLE I}

The Effect of TRH-Ab and NRS on Serum TSH and Prl Concentrations in Normal Male Rats

\begin{tabular}{lcccccc}
\hline & \multicolumn{3}{c}{ Serum TSH } & \multicolumn{3}{c}{ Serum Prl } \\
\hline & \multicolumn{3}{c}{$\mu U / m l$} & & & \\
& & & & & \\
Time $\min$ & 0 & 30 & 120 & 0 & 30 & 120 \\
TRH-Ab $(11)^{*}$ & $135 \pm 25 t$ & $57 \pm 9$ & $45 \pm 8$ & $29 \pm 4$ & $25 \pm 2$ & $32 \pm 5$ \\
NRS (9) & $147 \pm 20$ & $160 \pm 23$ & $163 \pm 34$ & $26 \pm 5$ & $30 \pm 3$ & $36 \pm 7$ \\
$P$ value & NS & $<0.001$ & $<0.005$ & NS & NS & NS \\
\hline
\end{tabular}

* Numbers in parentheses represent the number of rats per group.

t Mean $\pm \mathrm{SE}$.

$\S$ Student's $t$ test.

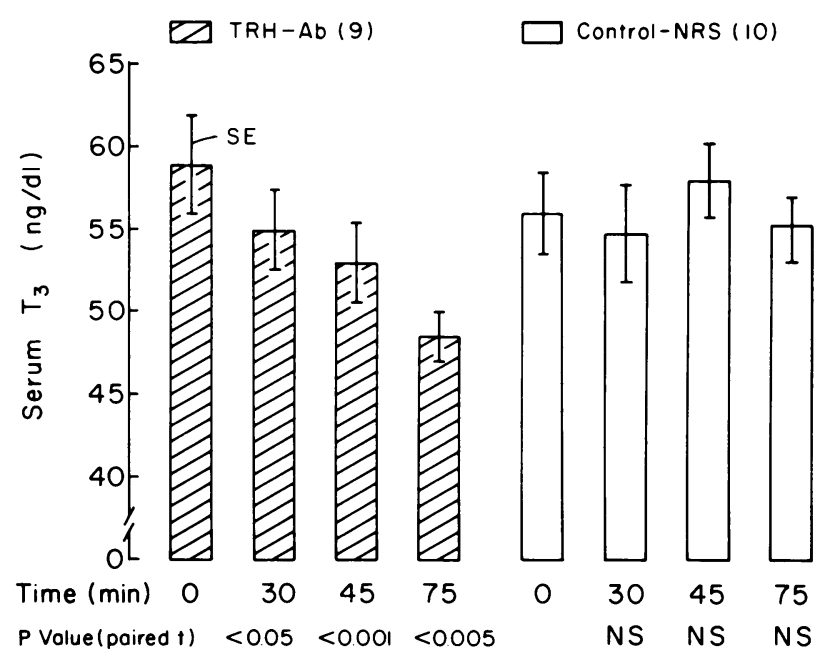

FIGURE 1 Effect of TRH-Ab on the serum $\mathrm{T}_{3}$ concentration in male rats. Bars and vertical lines represent group means $\pm S E$. Serum $\mathrm{T}_{3}$ values obtained after administration of TRH-Ab or NRS were compared to zero-time control sera using the paired $t$ test.

concentration was unchanged in rats given NRS $(3 \mathrm{~h}$, $111 \pm 3$ vs. $96 \pm 6 \mathrm{ng} / \mathrm{dl} ; 6 \mathrm{~h}, 106 \pm 9$ vs. $112 \pm 5 \mathrm{ng} / \mathrm{dl})$.

Effect of TRH-Ab on serum TSH and Prl concentration in the hypothyroid rat. The administration of TRH-Ab significantly decreased the elevated basal serum TSH concentration $(640 \pm 32 \mu \mathrm{U} / \mathrm{ml})$ at $30 \mathrm{~min}$ $(420 \pm 33 \mu \mathrm{U} / \mathrm{ml} ; P<0.001)$, and $60 \mathrm{~min}(425 \pm 37$ $\mu \mathrm{U} / \mathrm{ml} ; P<0.001$ ), but not at $120 \mathrm{~min}$ or $24 \mathrm{~h}$. NRS did not significantly lower the mean serum TSH concentration in these hypothyroid rats. Serum Prl concentrations

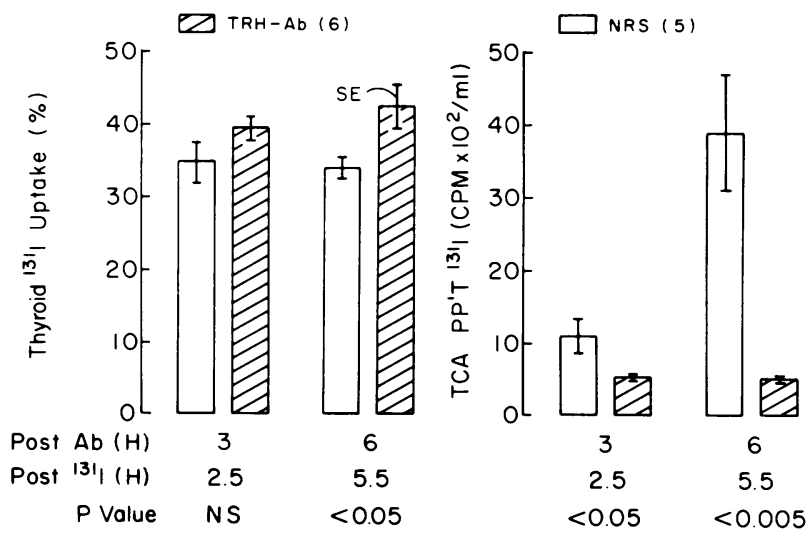

FIgURE 2 Effect of TRH-Ab on the thyroid ${ }^{131}$ I uptake and serum TCA precipitable ${ }^{131} \mathrm{I}$ in iodine-deficient ( $34 \mu \mathrm{g} \mathrm{I} / \mathrm{kg}$ for $3 \mathrm{wk})$ male rats. $30 \mathrm{~min}$ after TRH-Ab $(0.5 \mathrm{ml}$ i.v. $)$ or NRS $(0.5$ $\mathrm{ml}$ i.v.), $10 \mu \mathrm{Ci}^{131} \mathrm{I}$ was given i.v. and rats bled and sacrificed 2.5 or $5.5 \mathrm{~h}$ later. Rats given TRH-Ab $6 \mathrm{~h}$ earlier retained a significantly higher percentage of administered ${ }^{131} \mathrm{I}$ in the thyroid as compared to animals given NRS and also had markedly diminished serum TCA precipitable ${ }^{131} \mathrm{I}$ at 3 and $6 \mathrm{~h}$ after injection of antisera. 
TABLE II

The Effect of TRH-Ab and NRS on the Serum TSH and Prl Concentrations in Hypothyroid Male Rats

\begin{tabular}{|c|c|c|c|c|c|c|c|c|c|c|}
\hline \multirow{5}{*}{$\begin{array}{l}\text { Time } h \\
\text { TRH-Ab (10)* } \\
\text { NRS }(8)\end{array}$} & \multicolumn{5}{|c|}{ Serum TSH } & \multicolumn{5}{|c|}{ Serum Prl } \\
\hline & \multicolumn{5}{|c|}{$\mu U / m l$} & \multicolumn{5}{|c|}{$n g / m l$} \\
\hline & 0 & 0.5 & 1 & 2 & 24 & 0 & 0.5 & 1 & 2 & 24 \\
\hline & $640 \pm 32 \ddagger$ & $420 \pm 33$ & $425 \pm 37$ & $510 \pm 49$ & $560 \pm 21$ & $39 \pm 3$ & $23 \pm 2$ & $29 \pm 3$ & $30 \pm 3$ & $47 \pm 7$ \\
\hline & $660 \pm 28$ & $590 \pm 29$ & $560 \pm 35$ & $640 \pm 57$ & $600 \pm 25$ & $36 \pm 2$ & $24 \pm 2$ & $30 \pm 5$ & $24 \pm 5$ & $49 \pm 5$ \\
\hline$P$ value $\S$ & NS & $<0.005$ & $<0.02$ & NS & NS & NS & NS & NS & NS & NS \\
\hline
\end{tabular}

* Numbers in parentheses represent the number of rats per group.

$\ddagger$ Mean \pm SE.

$\$$ Student's $t$ test.

were similar in rats receiving TRH-Ab or NRS (Table II).

In another experiment, the suppressive effect of TRH-Ab on serum TSH persisted for $2 \mathrm{~h}$ (basal $1,012 \pm 71$ vs. 2 h, $696 \pm 112$; student's $t$ test, $P<0.05$ ).

To exclude the possibility that the decrease in serum TSH after TRH-Ab in the hypothyroid rat was due to hyperimmune rabbit serum per se, various TRH antisera were administered to groups of hypothyroid rats (Fig. 3). As was observed with NRS, low potency TRH-Ab $(1: 4,000)$ did not decrease serum TSH concentration at $30 \mathrm{~min}$. In contrast, high potency TRH-Abs significantly decreased serum TSH concentration 30 min after their administration. The greatest inhibition was induced by the most potent antibody $(1: 50,000)$, resulting in a $65 \%$ decrease at $30 \mathrm{~min}$. The decrease in the mean serum TSH concentration persisted for at least $60 \mathrm{~min}$ in the rats receiving the three most potent antibodies.

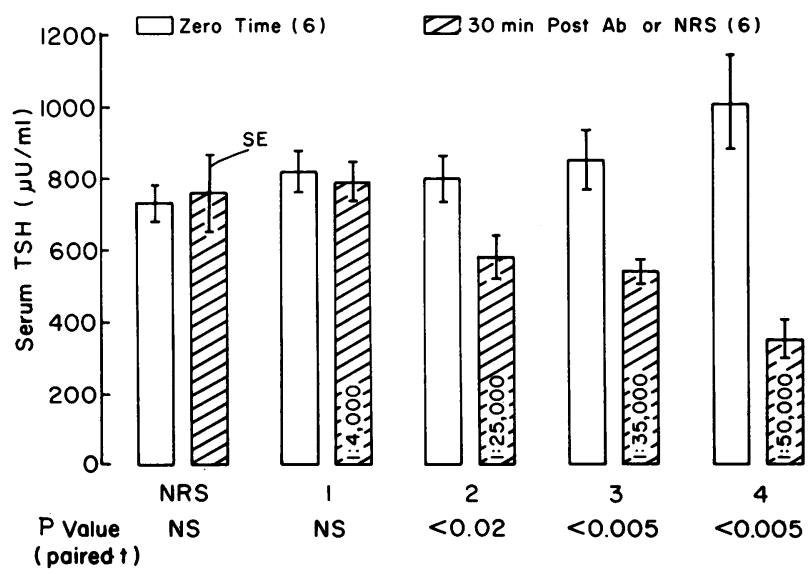

Figure 3 Effect of different TRH-Ab's $(0.1 \mathrm{ml}$ i.v.) on the mean serum TSH concentration in thyroidectomized rats. The final TRH-Ab dilution that binds $30 \%$ of labeled TRH in the TRH radioimmunoassay is shown within the hatched bars. Zero-time control serum samples were compared to samples obtained $30 \mathrm{~min}$ after injection of TRH-Ab's or NRS using the paired $t$ test.
Effect of TRH-Ab on the cold-induced increase in serum TSH and Prl concentrations. Exposure of rats to $4^{\circ} \mathrm{C}$ for $3 \mathrm{~h}$ resulted in a highly significant increase in serum TSH concentration $(59 \pm 12$ vs. $147 \pm 15$; paired $t$ test, $P<0.001$ ) (Fig. 4). The administration of TRH-Ab before cold exposure not only prevented the coldinduced rise in serum TSH but decreased serum TSH to undetectable or very low values. In another experiment (Table III), short-term $(60 \mathrm{~min})$ exposure of rats to the cold $\left(4^{\circ} \mathrm{C}\right)$ markedly increased the serum Prl concentration. TRH-Ab did not prevent this cold-induced rise in serum Prl concentration.

Effect of TRH-Ab on the serum Prl surge in the proestrus rat. The administration of TRH-Ab or NRS at 12:30 p.m. did not prevent the afternoon Prl or LH surge (Table IV). At 3 p.m., serum $\mathrm{Prl}$ was significantly higher in rats receiving TRH-Ab $(P<0.05)$. In these

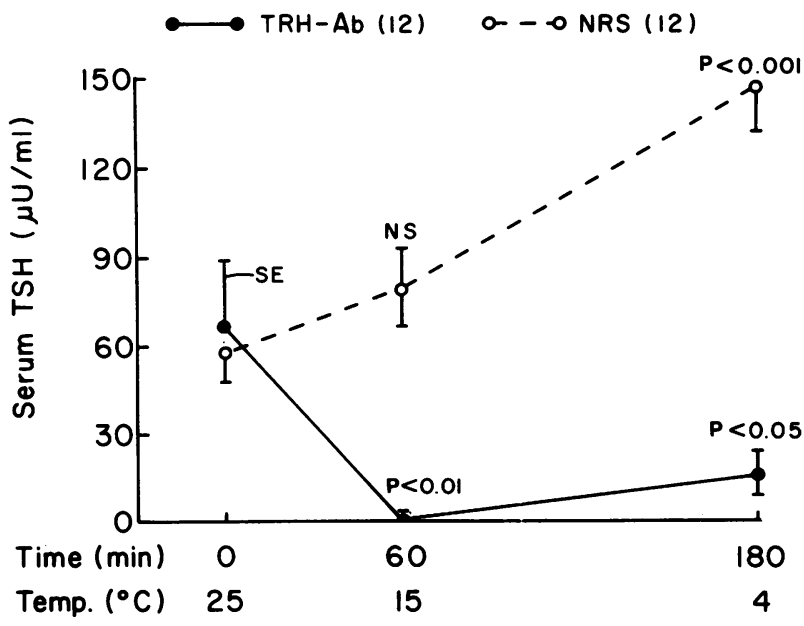

FIgURE 4 Effect of TRH-Ab on the cold-induced TSH rise in male rats. Immediately after zero time, control blood specimens were obtained, rats given TRH-Ab or NRS and the environmental room cooled from $25^{\circ} \mathrm{C}$ to $15^{\circ} \mathrm{C}$ at $60 \mathrm{~min}$ and further reduced to $4^{\circ} \mathrm{C}$ over the next $120 \mathrm{~min}$. Zero-time serum TSH concentrations were compared to levels obtained 60 and $180 \mathrm{~min}$ after cold exposure and significance assessed by the paired $t$ test. 
TABLE III

The Effect of TRH-Ab and NRS on the Cold-Induced Increase in Serum Prl Concentration in Male Rats

\begin{tabular}{lccccc}
\hline \multicolumn{5}{c}{ Serum Prl } \\
\hline & & $n g / m l$ & \\
Time* $_{\text {TRH-Ab (6) } \downarrow}$ & 0 & $10 \mathrm{~min}$ & $25 \mathrm{~min}$ & $60 \mathrm{~min}$ & $24 \mathrm{~h}$ \\
NRS (6) & $68 \pm 7 \S$ & $378 \pm 121$ & $212 \pm 132$ & $154 \pm 114$ & $48 \pm 16$ \\
$P$ value" & $103 \pm 21$ & $441 \pm 175$ & $232 \pm 112$ & $44 \pm 12$ & $32 \pm 5$ \\
& NS & NS & NS & NS & NS \\
\hline
\end{tabular}

* Cage temperature $4^{\circ} \mathrm{C}, 0-60 \mathrm{~min}$.

Numbers in parentheses represent the number of rats per group.

$\$$ Mean \pm SE.

"Student's $t$ test.

rats, TRH-Ab significantly suppressed TSH concentrations. In view of the slightly enhanced Prl surge in the proestrus rats given TRH-Ab, the experiment was repeated. Serum Prl concentrations were not significantly different in rats receiving either TRH-Ab or NRS. ( 11 a.m., $50 \pm 13$ (TRH-Ab) vs. $71 \pm 18 \mathrm{ng} / \mathrm{ml}$ (NRS); 1 p.m., $374 \pm 132$ vs. $260 \pm 77 ; 3$ p.m., $1,188 \pm 21$ vs. $800 \pm 275$; 5 p.m., $1,428 \pm 244$ vs. $1,490 \pm 333$ ).

\section{DISCUSSION}

The administration of TRH-Ab to the normal rat induced a rapid decrease in the mean serum TSH concentrations within $30 \mathrm{~min}$ which persisted for $\cong 2 \mathrm{~h}$, providing compelling evidence that, under physiologic conditions, secretion of TRH is required to sustain TSH release from the pituitary. Also, the enhanced secretion of TSH after cold exposure was inhibited in rats pretreated with TRH-Ab. These findings indicate that the cold-induced rise in TSH secretion is mediated by TRH as suggested by others $(25,33,39)$.

Several findings from the present study demonstrate that the decreased TSH secretion assessed by measurement of serum TSH by RIA was associated with decreased biological activity as well. First, the serum $T_{3}$ concentration in normal rats decreased significantly after TRH-Ab administration. Moreover, in iodine- deficient rats, in which serum $\mathrm{T}_{3}$ is primarily derived from thyroid secretion rather than from peripheral conversion of $\mathrm{T}_{4}(40,41)$, administration of $\mathrm{TRH}-\mathrm{Ab}$ resulted in a marked decrease in serum $\mathrm{T}_{3}$ concentration. A similar decrease in serum $T_{3}$ has been seen after the administration of TSH-Ab (42). Second, the TCA precipitable ${ }^{131} \mathrm{I}$, representing secreted ${ }^{131} \mathrm{I}-\mathrm{T}_{4}$ and $\mathrm{T}_{3}$, was dramatically decreased after TRH-Ab administration. Third, the thyroid ${ }^{131}$ I uptake was higher in the TRH-Ab-treated rats as compared to control rats, indicating a rapid decrease in circulating TSH (36).

The role of TRH in the secretion of TSH in hypothyroidism has been questioned. Hypothalamic lesioned, thyroidectomized rats exhibit a substantial rise in serum $\mathrm{TSH}$, despite a probable reduction in portal blood TRH concentrations $(10,43)$. Small doses of $\mathrm{T}_{4}$, insufficient to decrease the elevated serum TSH in the nonlesioned, thyroidectomized rats, were effective in suppressing TSH in the hypothalamic-lesioned, thyroidectomized animals, suggesting that, in the absence of TRH, the negative feedback of thyroid hormones at the pituitary is more pronounced. Furthermore, after completion of our studies, Mueller et al. (44) reported in abstract form that serum TSH was not decreased $2 \mathrm{~h}$ after TRH-Ab was administered to thyroidectomized rats. The present studies, however, suggest that TRH is at least partially responsible for sustained TSH secretion observed in primary hypothyroidism. Injection of four different TRH antisera to thyroidectomized rats resulted in a substantial decrease in serum TSH 30 and 60 min later, an effect that persisted for $2 \mathrm{~h}$ in one experiment. Another TRH antiserum with a weak titer $(1: 4,000)$ had no effect on serum TSH. It is possible, therefore, that the antiserum used by Mueller et al. was not sufficiently potent $(1: 8,000)$ to neutralize TRH in the pituitary portal circulation. Furthermore, the intraperitoneal injection of TRH-Ab used by these workers may have resulted in erratic absorption of antibody (33). In their experiments, earlier serum samples might have demonstrated a decrease in serum TSH concentration since, in our

TABLE IV

The Effect of TRH-Ab and NRS on the Proestrus Serum Prl and Luteinizing Hormone Surges and TSH Concentration in Normal Female Rats

\begin{tabular}{|c|c|c|c|c|c|c|c|c|}
\hline Time & \multicolumn{4}{|c|}{ TRH-Ab* } & \multicolumn{4}{|c|}{ NRS* } \\
\hline Prolactin $n g / m l$ & $23 \pm 6$ & $189 \pm 55$ & $1,490 \pm 260 \rrbracket$ & $1,570 \pm 286$ & $26 \pm 8$ & $134 \pm 27$ & $519 \pm 198$ & $1,394 \pm 168$ \\
\hline $\mathrm{TSH} \mu U / m l$ & $57 \pm 10$ & $20 \pm 3$ & $13 \pm 4$ & $19 \pm 3$ & $31 \pm 4$ & $31 \pm 9$ & $30 \pm 4$ & $38 \pm 5$ \\
\hline$P$ value $\S$ & & $<0.01$ & $<0.02$ & $<0.005$ & & NS & NS & NS \\
\hline
\end{tabular}

* $0.1 \mathrm{ml}$ administered i.v. at 12:30 p.m.

$\neq P<0.05$ when compared to 3 p.m. NRS.

$\S$ Paired $t$ test, TSH, vs. 11 a.m. 
studies, the decrease in serum TSH persisted up to $2 \mathrm{~h}$ in only one experiment. Serum TRH has been reported to be similar in the normal and hypothyroid rat $(39,45)$ and the serum TRH degrading enzyme activity lower in hypothyroid man and rat $(46,47)$. Furthermore, the metabolic clearance rate of TRH has been reported to be substantially decreased in hypothyroid rats (48). Thus, the production rate may be decreased or unaltered. It is not clear, therefore, why administration of $0.1 \mathrm{ml}$ of TRH-Ab resulted in a less pronounced decrease in the serum TSH concentration in the hypothyroid as compared to the normal rat. This may be due to failure of the antiserum to completely neutralize portal TRH. A small quantity of TRH remaining in the portal blood might be sufficient to sustain TSH secretion, a postulate consistent with the known enhanced sensitivity of the pituitary gland to TRH in primary hypothyroidism. An alternate explanation is provided by the recent demonstration that heterotopic pituitaries implanted under the renal capsule, and, therefore, lacking direct hypothalamic TRH control, are responsive to thyroid hormone deprivation as evidenced by enhanced TSH secretion (49). In hypothyroidism, therefore, the less pronounced decrease in serum TSH observed after TRH-Ab administration may be due to sustained pituitary TSH secretion despite complete TRH neutralization. However, further studies are required to clarify this hypothesis.

The demonstration that pharmacologic doses of TRH administered in vivo results in a concomitant release of TSH and Prl has been regarded as evidence that endogenous TRH may be involved in Prl regulation in man and rat. Further support for the role of TRH in prolactin secretion is obtained from studies in vitro in which TRH induces $\mathrm{Prl}$ release from $\mathrm{GH}_{3}$ cells (50) and rat pituitary cell cultures (51). Furthermore, preliminary data suggest that both serum TSH and serum Prl concentrations rise during proestrus in the rat (52). In the present study, however, the administration of TRH-Ab failed to decrease serum Prl in normal, proestrus, cold-exposed and hypothyroid rats even though serum TSH was strikingly decreased. It was also found that TRH-Ab did not decrease the proestrus luteinizing hormone surge.

Since completion of our study, Koch et al. (53) reported that $1 \mathrm{ml}$ of TRH-Ab administered intraperitonealy resulted in a decrease in serum $\mathrm{Prl}$ in normal, diestrus, and proestrus rats. The explanation for the difference in the Prl response to TRH-Ab between their study and the present findings is not readily apparent. The large volume of sera used by these workers would have resulted in different quantities of $\gamma$-globulin injection in TRH-Ab-treated, as compared to their NRS-treated control animals, and this may have interfered with the double antibody Prl RIA. Also, the different route of TRH-Ab administration and the use of ether anesthesia to obtain blood by heart puncture may have influenced their results since diestrus Prl values were elevated, suggesting stress. Furthermore, in their proestrus experiment, only one serum sample was obtained at 3 p.m. and the Prl values were not sufficiently elevated to indicate peak proestrus levels. The proestrus prolactin surge may have been delayed in this group of antibody-treated rats irrespective of the treatment employed, because we have frequently observed delays in the Prl surge in proestrus rats.

The present study strongly suggests that endogenous TRH secretion is required for TSH secretion in the rat under a variety of circumstances. It is apparent, however, that endogenous TRH is probably not required for the physiologic control of Prl secretion. Whether these findings in the rat can be extrapolated to man remains to be investigated.

\section{ACKNOWLEDGMENT}

This work was supported in part by grants AM18919 and HD 0944 from the National Institutes of Health.

\section{REFERENCES}

1. Jacobs, L. S., P. J. Snyder, J. F. Wilber, R. D. Utiger, and W. H. Daughaday. 1971. Increased serum prolactin after administration of synthetic thyrotropin releasing hormone (TRH) in man. J. Clin. Endocrinol. Metab. 33: 996-998.

2. Bowers, C. Y., H. G. Friesen, P. Hwang, H. J. Guyda, and K. Folkers. 1971. Prolactin and thyrotropin release in man by synthetic pyroglutamyl-histidyl-prolinamide. Biochem. Biophys. Res. Commun. 45: 1033-1041.

3. Hershman, J. M., A. Kojima, and H. G. Friesen. 1973. Effect of thyrotropin releasing hormone on human pituitary thyrotropin, prolactin, placental lactogen and chorionic thyrotropin. J. Clin. Endocrinol. Metab. 36: 497-501.

4. Mueller, G. P., H. J. Chen, and J. Meites. 1973. In vivo stimulation of prolactin release in the rat by synthetic TRH. Proc. Soc. Exp. Biol. Med. 144: 613-615.

5. D'Angelo, S. A., N. R. Wall, C. Y. Bowers, and C. G. Rosa. 1975. Effects of acute and chronic administration of TRH on TSH and prolactin secretion in normal and hypothyroid rats. Neuroendocrinology. 18: 161-175.

6. Greer, M. A. 1952. The role of the hypothalamus in the control of thyroid function. J. Endocrinol. Metab. 12: 1259-1268.

7. Bogdonove, E. M., and N. S. Halmi. 1953. Effects of hypothalamic lesions and subsequent propylthiouracil treatment on pituitary structure and function in the rat. Endocrinology. 53: 274-292.

8. Reichlin, S. 1957. The effect of hypothalamic lesions upon the thyroid response to partial thyroidectomy. Endocrinology. 60: 567-569.

9. Panda, J. N., and C. W. Turner. 1962. Hypothalamic control of thyrotropin secretion. J. Physiol. (Lond.). 192: $1-12$.

10. Reichlin, S., J. B. Martin, M. A. Mitnick, R. L. Boshans, Y. Grimm, J. Bollinger, J. Gordon, and J. Malacara. 1972. The hypothalamus in pituitary-thyroid regulation. Recent. Prog. Horm. Res. 28: 229-286.

11. Chen, C. L., Y. Amenomorio, K. H. Lu, J. L. Voogt, and J. 
Meites. 1970. Serum prolactin levels in rats with pituitary transplants or hypothalamic lesions. Neuroendocrinology. 6: 220-227.

12. Bishop, W., C. P. Fawcett, L. Krulich, and S. M. McCann. 1972. Acute and chronic effects of hypothalamic lesions on the release of $\mathrm{FSH}, \mathrm{LH}$, and prolactin in intact and castrated rats. Endocrinology. 91: 643-656.

13. Krulich, L., E. Hefco, and J. E. Aschenbrenner. 1975. Mechanism of the effects of hypothalamic de-afferentation on prolactin secretion in the rat. Endocrinology. 96: 107-118.

14. Halasz, B., L. Pupp, and S. Uhlarik. 1962. Hypophysiotrophic area in the hypothalamus. J. Endocrinol. 25: 147-154.

15. Harris, G. W., and J. W. Woods. 1958. The effect of electrical stimulation of the hypothalamus or pituitary gland on thyroid activity. J. Physiol. (Lond.). 143: 246-274.

16. Kalra, S. P., K. Ajika, L. Krulich, C. P. Fawcett, M. Quijada, and S. M. McCann. 1971. Effects of hypothalamic and preoptic electrochemical stimulation on gonadotropin and prolactin release in proestrus rats. Endocrinology. 88: 1150-1158.

17. Blake, C. A. 1974. Stimulation of pituitary prolactin and TSH release in lactating and proestrus rats. Endocrinology. 94: 503-508.

18. Burnet, F. R., and J. B. Wakerley. 1976. Plasma concentrations of prolactin and thyrotropin during suckling in urethane anesthetized rats. J. Endocrinol. 70: 429-437.

19. Gautvik, K. M., A. H. Tashjian, I. A. Kourides, B. D. Weintraub, C. T. Graeber, F. Maloof, K. Suzuki, and J. E. Zukerman. 1974. Thyrotropin-releasing hormone is not the sole physiotropic mediator of prolactin release during suckling. N. Engl. J. Med. 290: 1162-1166.

20. L'Hermite, M., C. Robyn, J. Golstein, G. Rothenbuchner, J. Birk, U. Loos, M. Bonnyns, and L. Vanhaelst. 1974. Prolactin and thyrotropin in thyroid diseases: lack of evidence for a physiological role of thyrotropin-releasing hormone in the regulation of prolactin secretion. Horm. Metab. Res. 6: 190-195.

21. Edwards, C. R. W., I. A. Forsyth, and G. M. Besser. 1971. Amenorrhea, galactorrhea, and primary hypothyroidism with high circulating levels of prolactin. Br. Med. J. 3: 462-464.

22. Miyai, K., T. Onishi, M. Hosokawa, K. Ishibashi, and Y. Kumahara. 1974. Inhibition of thyrotropin and prolactin secretions in primary hypothyroidism by $2-\mathrm{Br}$ - $\alpha$-ergocryptine. J. Clin. Endocrinol. Metab. 39: 391-394.

23. Boroditsky, R. S. and C. Faiman. 1973. Galactorrheaamenorrhea due to primary hypothyroidism. Am. J. Obstet. Gynecol. 116: 661-665.

24. Kleinberg, D. L., G. L. Noel, and A. G. Frantz. 1977. Galactorrhea: A study of 235 cases including 48 with pituitary tumors. N. Engl. J. Med. 296: 589-600.

25. Jobin, M., L. Ferland, and F. Labrie. 1975. Effect of exposure to cold on hypothalamic TRH activity and plasma levels of TSH and prolactin in the rat. Neuroendocrinology. 18: 204-212.

26. Jobin, M., L. Ferland, and F. Labrie. 1976. Effect of pharmacological blockage of ACTH and TSH secretion on the acute stimulation of prolactin release by exposure to cold and ether stress. Endocrinology. 99: 146-151.

27. Arimura, A., W. D. Smith, and A. V. Schally. 1976. Blockage of the stress-induced decrease in blood $\mathrm{GH}$ by anti-somatostatin serum in rats. Endocrinology. 98: 548555.

28. Tanjasiri, P., X. Kozbur, and W. H. Florsheim. 1976.
Somatostatin in the physiologic feedback control of thyrotropin secretion. Life Sci. 19: 657-660.

29. Terry, L. C., J. O. Willoughby, P. Brazeau, and J. B. Martin. 1976. Antiserum to somatostatin prevents stress-induced inhibition of growth hormone secretion in the rat. Science (Wash. D. C.). 192: 565-566.

30. Arimura, A., H. Sato, T. Kumasaka, R. B. Worobec, L Debeljuk, T. Dunn, and A. V. Schally. 1973. Production of antiserum to LH-releasing hormone (LH-RH) associated with gonadal atrophy in rabbits: Development of radioimmunoassays for LH-RH. Endocrinology. 93: $1092-1103$.

31. Kerdelhué, B., S. Catin, and M. Jutisz. 1975. In M. Motta, P. G. Crosigna, and L. Martini, Eds., Hypothalamic Hormones. Academic Press Inc. Ltd., London, 43-56.

32. McCormack, J. T., T. M. Plant, D. L. Hess, and E. Knobil. 1977. The effects of luteinizing hormone releasing hormone (LHRH) antiserum administration on gonadotropin secretion in the Rhesus monkey. Endocrinology. 100: 663-667.

33. Szabo, M. and L. A. Frohman. 1976. Suppression of cold-stimulated TSH secretion in the rat by anti-TRH serum. The Endocrine Society, 58th Annual Meeting, June 23-25, 265. (Abstr.)

34. Bassiri, R. M., and R. D. Utiger. 1972. The preparation and specificity of antibody to thyrotropin-releasing hormone. Endocrinology. 90: 722-727.

35. Vagenakis, A. G., E. Roti, J. Mannix, and L. E. Braverman. 1975. Problems in the measurement of urinary TRH. $J$. Clin. Endocrinol. Metab. 41: 801-804.

36. Greer, M. A., K. Inoue, A. Kajihara and C. F. Allen. 1970. Paradoxical increase in acute thyroid radioiodine accumulation following hypophysectomy in iodine-deficient rats. Endocrinology. 87: 1094-1096.

37. Mitsuma, T., J. Colucci, L. Shenkman, and C. S. Hollander. 1972. Rapid simultaneous radioimmunoassay for triiodothyronine and thyroxine in unextracted serum. Biochem. Biophys. Res. Commun. 46: 2107-2113.

38. Snedecor, G. W. 1956. Statistical methods applied to experiments in agriculture and biology. Iowa State University Press, Ames, Iowa, 5th edition.

39. Montoya, E., M. J. Seibel, and J. F. Wilber. 1975. Thyrotropin-releasing hormone secretory physiology: Studies by radioimmunoassay and affinity chromatography. Endocrinology. 96: 1413-1418.

40. Abrams, G. M., and P. R. Larsen. 1973. Triiodothyronine and thyroxine in the serum and thyroid glands of iodine-deficient rats. J. Clin. Invest. 52: 2522-2531.

41. Riesco, G., A. Taurog, P. R. Larsen, and L. Krulich. 1977. Acute and chronic responses to iodine deficiency in rats. Endocrinology. 100: 303-313.

42. Nejad, I. F., J. A. Bollinger, M. Mitnick, and S. Reichlin. 1973. Importance of $T_{3}$ (triiodothyronine) secretion in altered states of thyroid function in the rat: cold exposure, subtotal thyroidectomy, and hypophysectomy. Trans. Assoc. Am. Physicians. 85: 295-308.

43. Fukuda, H. and M. A. Greer. 1977. The effect of basal hypothalamic isolation on pituitary-thyroid activity and the response to propylthiouracil. Endocrinology. 100: 911-917.

44. Mueller, G., F. S. Franco, S. Reichlin, and I. D. M. Jackson. 1977. Elevated serum thyrotropin (TSH) of myxedema does not require continuous thyrotropin releasing hormone (TRH) secretion. Clin. Res. 24: 298A. (Abstr.)

45. Emerson, C. H., and R. D. Utiger. 1975. Plasma thyrotropin-releasing hormone concentrations in the rat. $J$. Clin. Invest. 56: 1564-1570. 
46. Dupont, A., F. Labrie, L. Levasseur, J. H. Dussault, and A V. Schally. 1976. Effects of thyroxine on the inactivation of thyrotropin-releasing hormone by rat and human plasma. Clin. Endocrinol. 5: 323-330.

47. White. N., S. L. Jeffcoate, E. C. Griffiths, and K. C. Hooper 1976. Effect of thyroid status on the thyrotropin-releasing hormone degrading activity of rat serum. J. Endocrinol. 71: $13-19$.

48. Jackson, I. M. D., P. D. Papapetrou, and S. Reichlin. 1974 The metabolism and excretion of TRH in the rat in states of altered thyroid function. 50th Meeting Am. Thyroid Assoc. T-1. (Abstr.)

49. Greer, M. A., N. Tonooka, and M. E. Thompson. 1977. Evidence that TRH and prolactin-release inhibiting factor (PIF) do not enter the general circulation in physiologi- cally significant amounts. 53rd Meeting Am. Thyroid Assoc. T-23. (Abstr.)

50. Dannies, P. S. and A. H. Tashjian. 1974. Pyroglutamylhistidyl-prolineamide (TRH). A neurohormone which affects the release and synthesis of prolactin and thyrotropin. Isr. J. Med. Sci. 10: 1294-1304.

51. Vale, W., R. Blackwell, G. Grant, and R. Guillemin. 1973. TRF and thyroid hormones on prolactin secretion by rat anterior pituitary cells in vitro. Endocrinology. 93: 26-33.

52. Brown-Grant, K., A. Dutton, and M. B. ter Haar. 1977. Variations in plasma thyrotropin concentration during the rat oestrus cycle. J. Endocrinol. 72: 33-34. (Abstr.)

53. Koch, Y., G. Goldhaber, I. Fireman, U. Zor, J. Shani, and E. Tal. 1977. Suppression of prolactin and thyrotropinreleasing hormone. Endocrinology. 100: 1476-1478. 